\title{
The naturally competent strain Streptococcus thermophilus LMD-9 as a new tool to anchor heterologous proteins on the cell surface
}

Xavier Lecomte ${ }^{1,2,3,4}$, Valérie Gagnaire ${ }^{3,4}$, Valérie Briard-Bion ${ }^{3,4}$, Julien Jardin ${ }^{3,4}$, Sylvie Lortal ${ }^{3,4}$, Annie Dary ${ }^{1,2}$ and Magali Genay ${ }^{1,2^{*}}$

\begin{abstract}
Background: From fundamental studies to industrial processes, synthesis of heterologous protein by micro-organisms is widely employed. The secretion of soluble heterologous proteins in the extracellular medium facilitates their recovery, while their attachment to the cell surface permits the use of the recombinant host cells as protein or peptide supports. One of the key points to carry out heterologous expression is to choose the appropriate host. We propose to enlarge the panel of heterologous secretion hosts by using Streptococcus thermophilus LMD-9. This lactic acid bacterium has a generally recognised as safe status, is widely used in the manufacture of yogurts, fermented milks and cheeses, and is easy to transform by natural competence. This study demonstrates the feasibility of secretion of a heterologous protein anchored to the cell surface by S. thermophilus. For this, we used the cell envelope proteinase (CEP) PrtH of Lactobacillus helveticus CNRZ32 CIRM-BIA 103.
\end{abstract}

Results: Using S. thermophilus LMD-9 as the background host, three recombinant strains were constructed: i) a negative control corresponding to $S$. thermophilus PrtS $^{-}$mutant where the prtS gene encoding its CEP was partially deleted; ii) a $\mathrm{PrtH}^{+}$mutant expressing the L. helveticus PrtH pro-protein with its own motif (S-layer type) of cell-wall attachment and iii) a PrtH ${ }^{+}$WANS mutant expressing PrtH pro-protein with the LPXTG anchoring motif from PrtS. The $\mathrm{PrtH}^{+}$and $\mathrm{PrtH}^{+}$WANS genes expression levels were measured by RT-qPCR in the corresponding mutants and compared to that of prtS gene in the strain LMD-9. The expression levels of both fused prtH CEPs genes, regardless of the anchoring motif, reached up-to more than $76 \%$ of the wild-type prts expression level. CEPs were sought and identified on the cell surface of LMD-9 wild-type strain, $\mathrm{PrtH}^{+}$and $\mathrm{PrtH}^{+}$WANS mutants using shaving technique followed by peptide identification with tandem mass spectrometry, demonstrating that the heterologous secretion and anchoring of a protein of more than $200 \mathrm{kDa}$ was efficient. The anchoring to the cell-wall seems to be more efficient when the LPXTG motif of PrtS was used instead of the S-layer motif of PrtH.

Conclusions: We demonstrated S. thermophilus LMD-9 could heterologously secrete a high molecular weight protein and probably covalently anchor it to the cell-wall.

Keywords: Heterologous expression, Secretion, Cell-wall anchored protein, Streptococcus thermophilus LMD-9, Cell envelope proteinase (CEP), PrtS, PrtH, Lactobacillus helveticus CNRZ32 CIRM-BIA 103

\footnotetext{
* Correspondence: magali.genay@univ-lorraine.fr

'Unité de Recherche Animal et Fonctionnalités des Produits Animaux, Equipe

Protéolyse et Biofonctionnalité des Protéines et des Peptides, Université de

Lorraine, Vandouvre-lès-Nancy F-54506, France

${ }^{2}$ INRA, UR AFPA Unité Sous Contrat 340, Vandœuvre-lès-Nancy F-54506,

France

Full list of author information is available at the end of the article
}

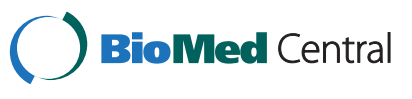

(c) 2014 Lecomte et al.; licensee BioMed Central Ltd. This is an Open Access article distributed under the terms of the Creative Commons Attribution License (http://creativecommons.org/licenses/by/2.0), which permits unrestricted use, distribution, and reproduction in any medium, provided the original work is properly credited. The Creative Commons Public Domain Dedication waiver (http://creativecommons.org/publicdomain/zero/1.0/) applies to the data made available in this article, unless otherwise stated. 


\section{Background}

Heterologous protein secretion is being increasingly employed to produce proteins on different living supports. Genetic tools have therefore been developed to present a protein or a peptide specifically on the surface of a microbial vector to study its structure, conformation, activity and/or interactions with its environment. Studies could be conducted in various conditions such as in a culture medium, in dairy matrix, or in vivo, for immune response (vaccination) or physiological effects in gastro intestinal tract $[1,2]$. In order to secrete heterologous proteins in the extracellular medium or anchor them to the cell-wall, the choice of the host is crucial and a panel of transformable species with their advantages and disadvantages is currently available [1]. The gram negative bacterium Escherichia coli is the most employed for intracellular heterologous expression, while the gram positive bacterium Bacillus subtilis is preferentially chosen for heterologous secretion $[1,3]$. B. subtilis also displays the advantage to be naturally competent. Indeed, it is possible in a one-step plasmid-free transformation to introduce into the cell and integrate in the chromosome by homologous recombination a foreign DNA. Lactic acid bacteria (LAB) have recently been used as alternative expression hosts to B. subtilis [4]. Among them, Lactococcus lactis presents several advantages, including many tools for genetic modifications, efficient protein secretion capability [4] and only few predicted cell surface proteins [5]. Furthermore, this bacterium possesses only one surface housekeeping protease, HtrA, able to degrade abnormal exported proteins and this protease gene can be inactivated to prevent the degradation of heterologously expressed proteins [4]. Finally, as this species has a generally recognised as safe (GRAS) status and is widely present in dairy products, it could be employed to study proteins behaviour in food (in situ) or in vivo which is not the case for B. subtilis. However, Lc. lactis still lacks the natural competence [6] in contrast to other food grade LAB [7] such as Streptococcus thermophilus.

S. thermophilus has a GRAS status and is widely used for its high acidification ability, in dairy products. This is one of the two dairy starters of yogurt and its recovery in faeces of human volunteers consuming yogurt has definitively established that this bacterium is capable to remain alive during its transit through the digestive tract $[8,9]$. Further, the production of active $\beta$-galactosidase in the second half of the small intestine by the strain FB13 further suggests that $S$. thermophilus remains metabolically active during its digestive transit. This could explain the improvement of lactose digestion observed in intolerant patients after yogurt consumption $[9,10]$.

Previous works demonstrated that S. thermophilus was able to express intracellular heterologous proteins. Mutants were obtained by electrotransformation and plasmids were used as gene vectors to produce intracellular heterologous proteins. For example, green fluorescent protein [11], Streptomyces cholesterol oxidase [12] and glutamate decarboxylase [13] were heterologously produced in S. thermophilus cytoplasm. The recent discovery of natural competence and its mechanisms in some S. thermophilus strains [14-16] allowed the introduction of heterologous genes in the bacterial cell by natural competence and their chromosomal insertion by double cross-over recombination. Since then, natural competence was used to insert linear DNA fragments corresponding to reporter genes such as the luciferase genes $\operatorname{lu} x A B$ [17] and the antibiotic resistant genes, i.e. cat for chloramphenicol [17], aphA3 for kanamycin or ery for erythromycin [18] which were intracellularly expressed. Now the challenge is to produce mutants able to export proteins on the cell surface and in this context, S. thermophilus LMD-9 could be a good candidate. Indeed, on the basis of its genome sequence, it is expected that this bacterium would display $2 / 3$ less cell surface proteins than Lc. lactis, which already have few proteins present at the surface [5]. A single cell envelope proteinase (CEP), named PrtS, with high molecular weight is predicted to be covently anchored onto the cell-wall by action of the sortase SrtA [19]. The secretion system exporting this CEP as well as the sortase SrtA could then be good candidates to secrete in the medium heterologous proteins of various molecular weights and to covalently anchor them onto the cell-wall. Further, as in the case of $L c$. lactis, the presence of a unique housekeeping protease gene, $h \operatorname{tr} A$, is an advantage compared to $B$. subtilis that possesses multiple housekeeping proteases able to degrade the exported proteins at the surface [3], and htrA of $S$. thermophilus can be deleted to avoid protein degradation. Finally, S. thermophilus has been detected in human gut by metagenomic sequencing [20], further make possible the use of this bacterium in in vivo studies. Therefore, it could be interesting to further develop genetic tools to produce heterologous proteins on the cell-wall of S. thermophilus LMD-9 strain.

To make the proof of concept that S. thermophilus can be used as a tool for the heterologous secretion of cell-wall anchored proteins, we decided to heterologously express the prtH gene of L. helveticus CNRZ32 in S. thermophilus LMD-9. Indeed, one of the main topics of our laboratories is the study of the activity and specificity of CEPs of lactic acid bacteria, particularly those of $S$. thermophilus and L. helveticus. The choice of this protease seemed coherent to us knowing that: i) S. thermophilus and L. helveticus CEP genes present similarities in the codon usage; ii) both bacteria are used as co-starters in the manufacturing of Swiss-type cheeses and thus grow in the same environment (milk medium, temperature, $\mathrm{pH}$...), thereby eliminating a potential influence of the environment on the conformation and activity of PrtH; iii) S. thermophilus possesses an active 
proteolytic system and so anything that seems necessary for the expression and activity of a protease; iv) proteolytic activity would be easy to detect as it is known to confer a growth advantage compared to strains that do not secrete a functional CEP [21,22]. Finally, this experiment may allow us to elucidate the specific role of PrtH in the proteolytic activity of L. helveticus CNRZ32 since four CEP genes were identified in its genome sequence designated as $p r t H$, prtH2, prtH3 and prtH4 and the role of each CEP has not been defined independently yet $[23,24]$.

\section{Results}

\section{Strategy of the mutant constructions for the heterologous} expression of PrtH on the cell-wall of S. thermophilus LMD-9 prtS of S. thermophilus and prtH of L. helveticus both encode high molecular weight proteins (above $180 \mathrm{kDa}$ ) secreted on the cell-wall and belonging to the subtilisinlike serine proteinase family. They display a similar organization, which can be separated into five regions important for our genetic constructions (Figure $1 \mathrm{~A}$ and $\mathrm{B}$ ): i) the promoter and the ribosome binding site (RBS); ii) the export signal with the signal sequence $(\mathrm{S})$ which addresses the protein to the secretory system (Sec system); iii) the different CEP domains: pro-peptide domain (PP), catalytic domain (PR), A domain (A), B domain (B) only for prtH and helix domain $(\mathrm{H})$; iv) the CEP fixation part consisting of a cell-wall spacer domain (W) and an anchor domain (AN) with a LPXTG anchoring motif for prtS, and of a cell-wall spacer domain (W) with a S-layer domain attachment at the C-terminal end for $p r t H$; v) a stop codon at the end of the last domain followed by a transcription terminator $[25,26]$. Three main parameters should be considered to achieve PrtH secretion and anchoring: the signal sequence, the transcription level of the CEP and the anchoring motif. As $S$. thermophilus LMD-9 expresses an active CEP on its cell-wall, we have chosen to use the expression/secretion pathway of PrtS to express and secrete the CEP of L. helveticus. Thus, our strategy to secrete PrtH was to replace the pro-protein sequence of prtS of S. thermophilus LMD-9 with the proprotein sequence of prtH of L. helveticus CNRZ32 (from the PP to the W domains), maintaining the promoter, RBS, and signal sequence of prtS (Figure $2 \mathrm{~A}$ and B).

Regarding the signal sequence, the use of the PRED TAT tool [27] revealed that both CEPs PrtS and PrtH have a signal peptide which addresses them to the Sec system. In gram positive bacteria, this general secretion pathway seems to imply the presence of a peculiar amino acid sequence which follows the signal peptide and could be recognised by the secretory system as previously demonstrated in Lc. lactis [2]. As both PrtS and PrtH are predicted to be secreted by the Sec system, this peculiar sequence should be functional in both CEPs. Therefore, we assumed that this peculiar sequence, located at the beginning of the PP domain of PrtH, would be functional in the Sec system of $S$. thermophilus. So only the $S$ domain of PrtS was systematically conserved in our protein constructions to preserve the entire PP domain of PrtH in S. thermophilus.

Concerning the anchoring, we decided to test two different cell-wall anchoring systems: either the one from PrtH (S-layer type) or that from PrtS (LPXTG). Indeed, the S-layer motif used by L. helveticus may be not adapted to the cell-wall of $S$. thermophilus and PrtH may not correctly interact with the cell-wall. Thus, to maximise the anchoring of the proteinase, we replaced its S-layer domain by the W and AN domains of PrtS.

\section{Constructions of $\mathrm{PrtH}^{+}, \mathrm{PrtH}^{+}$WANS and PrtS ${ }^{-}$mutants}

In order to heterologously express PrtH on the cell-wall of $S$. thermophilus LMD-9, we constructed two mutants with two different anchoring systems (Figure 2). The mutant constructions were based on the design of an overlapping PCR (OL PCR) fragment to join the different gene parts, the natural transformation of $S$. thermophilus with the OL PCR resulting fragment and its integration into the chromosome by double cross-over recombination. The first mutant, named $\mathrm{PrtH}^{+}$, was expected to secrete PrtH which exhibited at the C-terminal of its $\mathrm{W}$ domain a S-layer anchoring motif, thought to anchor PrtH to the L. helveticus cell-wall [24,28] (Figure 2A). The 8622 base pair (bp) construction (F1 to F4) allowed the insertion of a 6718 bp foreign DNA by double cross-over recombination, replacing a large part of the prtS locus in S. thermophilus LMD-9 chromosome. As expected, the heterologous fused gene comprised the promoter, the RBS and the Signal sequence (S domain) of prtS, the prtH ORF spanning from the PP domain to 46 nucleotides (nt) downstream the stop codon, an erythromycin resistance gene and the downstream region of prtS.

The second mutant, named $\operatorname{PrtH}^{+} \mathrm{WANS}$, derived from the first. The anchoring system of the $\mathrm{PrtH}^{+} \mathrm{mu}-$ tant was replaced by the prtS cell-wall spacer and the anchor domains (W and AN domains) of S. thermophilus (Figure 2B and Methods). This was chosen to favour the secretion and the anchoring of the PrtH CEP in the cellwall of $S$. thermophilus by covalent binding. Thus, a 4186 bp OL PCR fragment (Figure 2B; F5-F6-F7-F4) replaced by double cross-over recombination the prtH W domain (from the 97th nt of prtH W domain to the end of F3 fragment) by the F6 and F7 fragments.

During the construction of the $\mathrm{PrtH}^{+}$mutant, one of the erythromycin resistant clones was lacking the $\mathrm{prtH}$ gene fragment (F2) (Figure 2C). In this mutant, called $\mathrm{PrtS}^{-}$, the major part of prtS was replaced by an $89 \mathrm{nt}$ sequence and an erythromycin resistance gene, inserted between F1 and F4 fragments as described in the Methods section. This 89 nt sequence was produced 


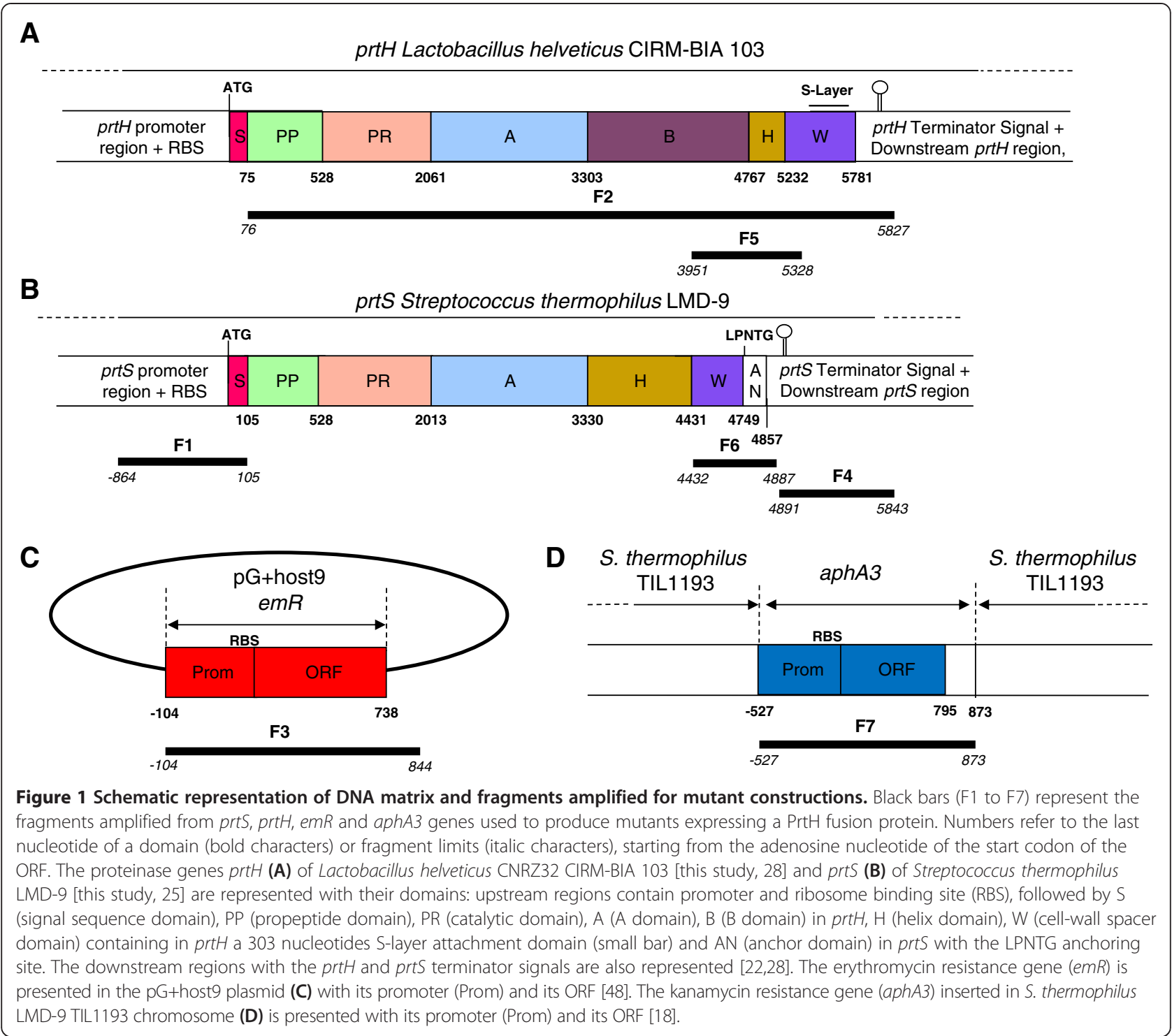

during the OL PCR amplification of $p r t H^{+}$fragment by the fusion of F1 and F3 tail fragments. This sequence was composed of the beginning of $p r t H$ PP domain directly fused to the 3' region of F2 (after prtH stop codon). These two fragments had mutations (data not shown) and the resulting 48 aa residues peptide was composed of prtS S domain (MKKKETFSLRKYKIGTVSVLLGAVFLFAGAPS VAA) followed by 13 aa residues (KQQVKASVDSQTK) similar to the N-terminal aa residues of the PrtH PP domain with one mutation changing the first aa residue glutamate (E) of the PP into a lysine residue (K). As PrtS mutant was deprived of the major part of prtS and no other CEP genes were present in $S$. thermophilus LMD-9 genome, this mutant was used as a negative control in this study.
For the three constructed mutants, the constructions were checked by sequencing, which also confirmed that no additional or unexpected mutations occurred in the three mutant sequences.

\section{Heterologous gene expressions}

The transcription of prtH $H^{+}$and $p r t H^{+}$WANS genes was investigated by real-time quantitative polymerisation chain reaction (RT-qPCR) during the exponential growth of S. thermophilus $\mathrm{PrtH}^{+}$and $\mathrm{PrtH}^{+} \mathrm{WANS}$ in milk (Figure 3). This medium was use to maximise the CEP gene expression. Indeed, to grow at high cellular density in milk, which is poor in free amino acids and peptides, $S$. thermophilus requires an efficient CEP activity to hydrolyse caseins into peptides for nitrogen supply, and this activity 


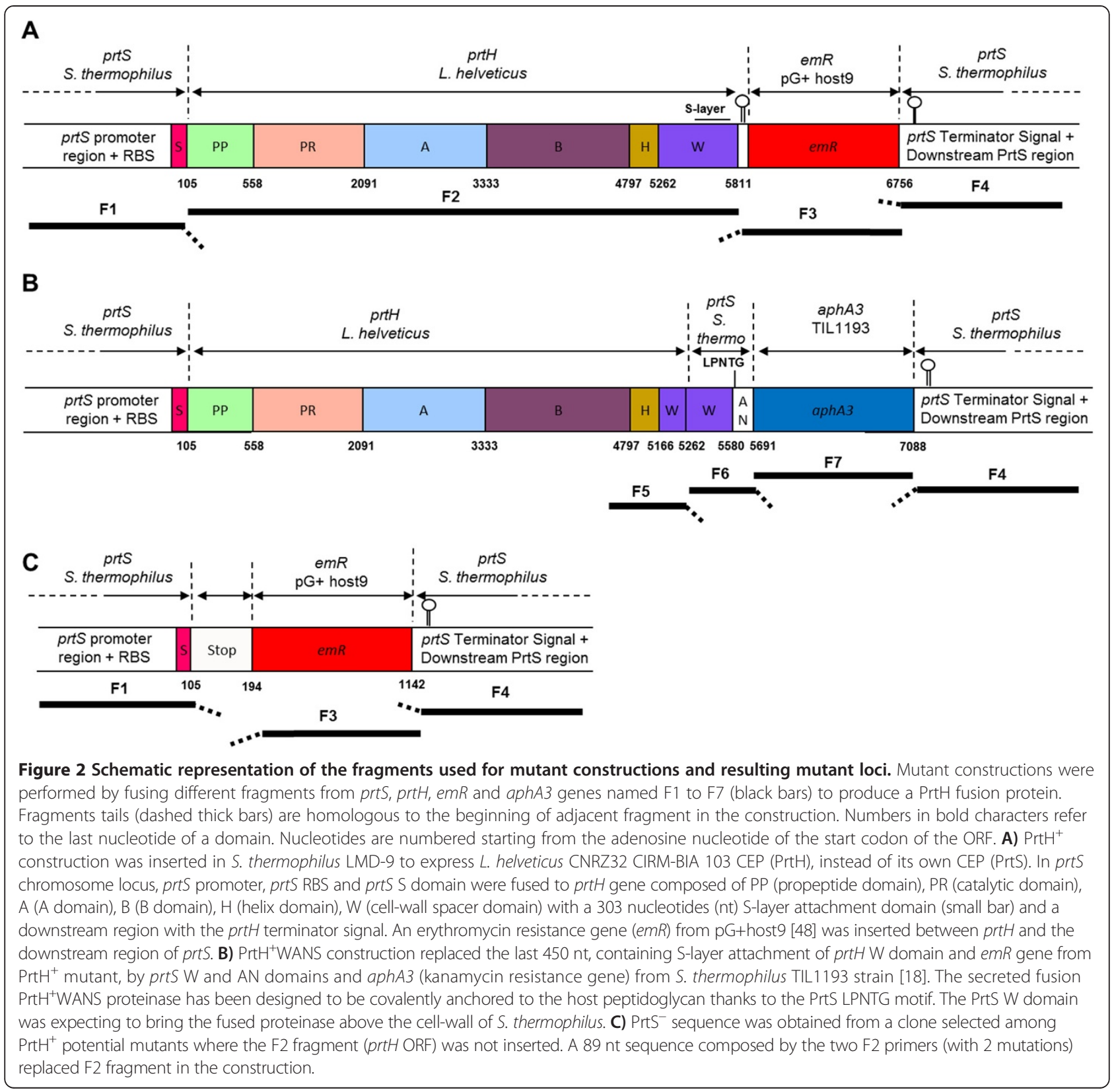

has been shown to be maximum during the exponential growth phase of the bacterium [29]. As expected, the prtS, prt $H^{+}$and $p r t H^{+} W A N S$ genes were expressed in $S$. thermophilus LMD-9 wild-type, $\operatorname{PrtH}^{+}$mutant and PrtH ${ }^{+}$WANS mutant, respectively. When compared with the expression level of the prtS gene in the wild-type strain, the $p r t H^{+}$and $p r t H^{+} W A N S$ genes appeared to be approximately $15 \%$ and $24 \%$ lower, respectively. No CEP gene expression was detected in the PrtS ${ }^{-}$mutant.

Although CEP genes were expressed in $\mathrm{PrtH}^{+}$and PrtH ${ }^{+}$WANS mutants, their growth in skim milk appeared to be very similar to that of the $\operatorname{PrtS}^{-}$mutant.
These three mutants grew slightly lower than the wildtype strain LMD-9. Indeed, the three mutants reached an optical density at $480 \mathrm{~nm}\left(\mathrm{OD}_{480 \mathrm{~nm}}\right)$ of 2 in five hours whereas the wild-type strain reached this OD in less than three hours. Additional activity tests were performed by using $\beta$ - and $\alpha_{\mathrm{s} 1^{-}}$caseins as substrate as described by Sadat-Mekmene et al. [30]. No CEP activity was detected neither on the cell surface nor in the extracellular culture medium of the $\mathrm{PrtH}^{+}$and $\mathrm{PrtH}^{+}$WANS mutants, whereas activity was detected for both wild-type strains $S$. thermophilus LMD-9 and L. helveticus CNRZ32 CIRM-BIA 103 (data not shown). However, as the strain CIRM-BIA 103 


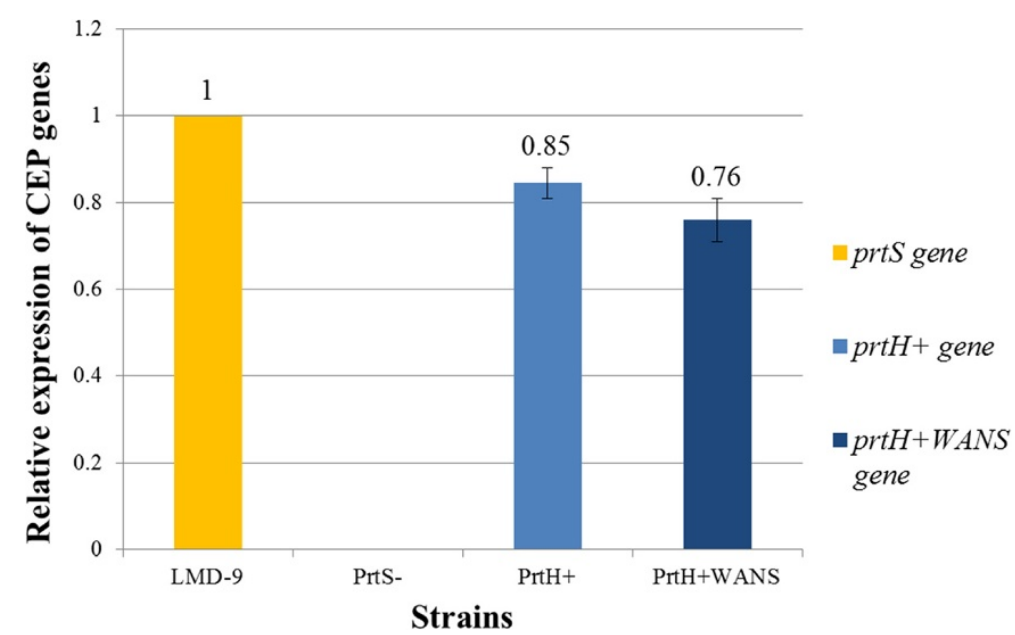

Figure 3 Relative expression of CEP genes in the mutants compared to prtS in S. thermophilus LMD-9. The expression of CEP genes (prtS, prtH $H^{+}$and prtH $H^{+}$WANS) was detected by RT-qPCR of S. thermophilus wild-type LMD-9 and PrtS ${ }^{-}$, PrtH ${ }^{+}$and PrtH ${ }^{+}$WANS mutant strains during the exponential growth phase in milk. CEP gene expressions were normalised with respect to the reference gene sigma70/sigma32 for each strain. The normalised expressions of $\mathrm{prtH}^{+}$and $\mathrm{prtH}^{+}$WANS CEP genes were compared to that of the reference prtS gene.

contains 4 protease genes, the detected activity may be due to one or more proteases and not necessarily to PrtH.

\section{Detection of the heterologous proteins expressed on the bacterial cell surface}

To detect the presence of the various proteinases at the surface of $S$. thermophilus LMD-9 wild-type and mutant strains, a shaving approach was used. This method consists in hydrolysing the cell surface proteins of the living bacteria by trypsin under mild conditions, and in identifying the peptides released from the surface proteins using chromatographic separation coupled on line with tandem mass spectrometry. For each sample, negative controls without trypsin (cf. Methods) were performed. The identified proteins are reported in Additional file 1: shaving results A. The three CEPs PrtS, PrtH ${ }^{+}$and PrtH ${ }^{+}$WANS were identified on the cell-wall of $S$. thermophilus LMD-9 wild-type strain, $\operatorname{PrtH}^{+}$and $\operatorname{PrtH}^{+}$WANS mutants, respectively (Table 1 and Additional file 1: shaving results $B$, C and D). All detected peptides were specific to trypsin hydrolysis (which cuts after lysyl and arginyl amino acid residues), suggesting that these peptides did not result from degradation by another protease. To estimate the coverage of each protein identified by LC-MS/MS experiments, the first step was to calculate the protein abundance index (PAI) which is the number of observed peptides divided by the number of observable peptides per protein. The second step was to calculate the exponentially modified protein abundance index (emPAI) from the PAI values as: emPAI $=10^{\mathrm{PAI}}-1$. Although shaving is first of all a qualitative method, the emPAI allows a semi quantitative estimation of proteins regarding each sample separately [31,32].

The emPAI of CEPs among identified proteins in the sample was 112.92 for PrtS, 6.86 for $\mathrm{PrtH}^{+}$and 161.66 for PrtH ${ }^{+}$WANS (Table 1). PrtS and PrtH ${ }^{+}$WANS were thus ranked among the most abundant proteins detected in their respective samples (Additional file 1: shaving results A). Those most abundant proteins were also predicted as cell surface proteins. So PrtH ${ }^{+}$WANS seemed to be present at the cell surface, probably anchored to the cell-wall as it is the case for PrtS. In contrast, $\mathrm{PrtH}^{+}$appeared to be less abundant among the identified proteins. Identified CEP peptides are presented in Figure 4 and in Additional file 1: shaving results $\mathrm{B}, \mathrm{C}$ and $\mathrm{D}$. For PrtS, 60 peptides were identified from the PP to $\mathrm{H}$ domains, while no peptides

Table 1 Proteinases identified after cell surface shaving of S. thermophilus strains PrtS ${ }^{-}$, LMD-9, PrtH ${ }^{+}$and PrtH ${ }^{+}$WANS

\begin{tabular}{|c|c|c|c|c|c|c|c|c|c|c|}
\hline \multirow[b]{2}{*}{ Description } & \multirow[b]{2}{*}{ Prot Id } & \multirow[b]{2}{*}{$\mathrm{MW}(\mathrm{kDa})$} & \multicolumn{2}{|c|}{ PrtS $^{-}$} & \multicolumn{2}{|c|}{ LMD-9 } & \multicolumn{2}{|c|}{$\mathrm{PrtH}^{+}$} & \multicolumn{2}{|c|}{ PrtH $^{+}$WANS } \\
\hline & & & $\mathrm{Nb}$ id pept & emPAl & $\mathrm{Nb}$ id pept & emPAI & $\mathrm{Nb}$ id pept & emPAI & $\mathrm{Nb}$ id pept & emPAl \\
\hline Subtilisin-like serine protease (PrtS) & Q03L35 & 172.9 & & & 60 & 112.92 & & & & \\
\hline $\mathrm{PrtH}^{+}$ & & 208.6 & & & & & 40 & 6.86 & & \\
\hline $\mathrm{PrtH}^{+}$WANS & & 206.0 & & & & & & & 82 & 161.66 \\
\hline
\end{tabular}

emPAl: exponentially modified Protein Abundance Index [31].

$\mathrm{Nb}$ id pept: number of identified peptides belonging to identified protein.

Prot Id: Identification sequence from the following databases TrEMBL. 


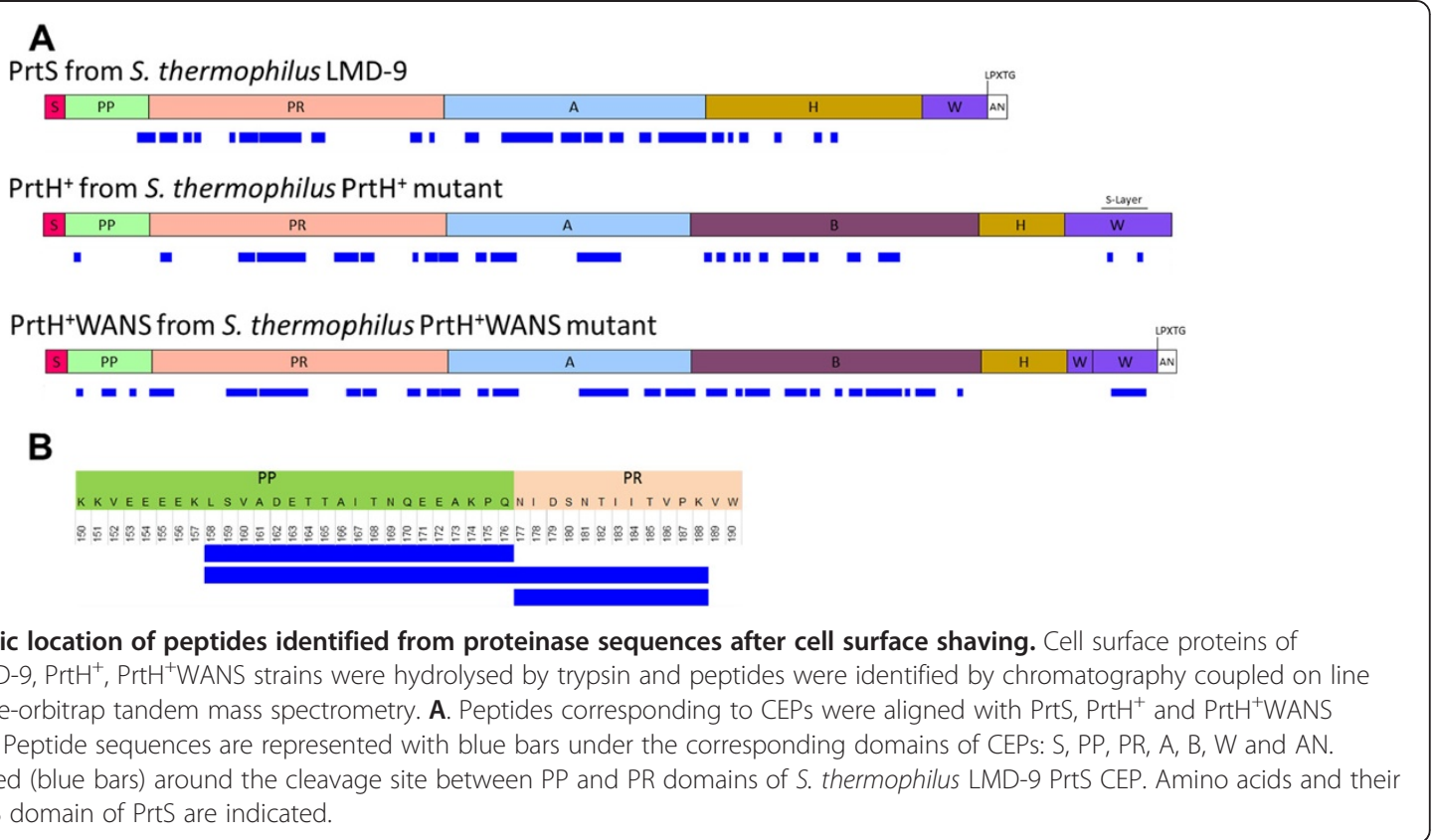

corresponded to the $\mathrm{S}, \mathrm{W}$ or $\mathrm{AN}$ domains (Figure 4A and Additional file 1: shaving results B). For $\mathrm{PrtH}^{+}, 40$ peptides were identified from the PP to the W domains except from the $\mathrm{H}$ domain, while no peptides corresponded to the $\mathrm{S}$ domain (Figure $4 \mathrm{~A}$ and Additional file 1: shaving results $\mathrm{C}$ ). Finally, 82 peptides covering the $\mathrm{PrtH}^{+}$WANS sequence from the PP to the PrtS W domains were detected while no peptides originating from the $\mathrm{S}$ and $\mathrm{AN}$ domains of PrtS or from the $\mathrm{H}$ and $\mathrm{W}$ domains of PrtH were detected (Figure 4A and Additional file 1: shaving results D). As expected, no CEP was identified on the cell surface of the PrtS ${ }^{-}$mutant.

\section{Discussion}

Although tools required for the expression of heterologous proteins in LAB have been recently developed [4], B. subtilis and $E$. coli remain the mostly employed bacteria [1,3]. However, the expression of proteins on the bacterial surface remains a challenge regardless the bacterial host because the final structure of the secreted protein is influenced by various parameters. For example, $\mathrm{pH}$, temperature or ionic environment can impair the final conformation and subsequent function of the heterologous protein. Moreover, the cell-wall composition (peptidoglycan, S-layer, ...), which differed from one species to another [33,34], should influence the protein environment. Thus, enlarging the host panel to express heterologous proteins on the cell surface offers new choices between various secretion or cell-wall anchoring systems. LAB host can also be used as vectors in various milk derived products. To the best of our knowledge, this study reports for the first time the secretion to the cell-wall of a high molecular weight heterologous protein (above
$200 \mathrm{kDa}$ ), i.e. the CEP PrtH of L. helveticus. Two mutants were constructed by natural transformation to secrete instead of the CEP PrtS of S. thermophilus LMD-9 wild-type strain, a PrtH (with its own S-layer attachment motif) and a PrtH ${ }^{+}$WANS protein (where the PrtH anchoring system was replaced by the PrtS one).

\section{CEPs identification and location by shaving}

To determine whether proteinases were really present on the cell surface, even at low level, we chose to shave the surface of the live cells of $S$. thermophilus wild-type and mutant strains by trypsin, a proteinase of well-known specificity, widely used in proteomics for protein identification by gel or gel-free based methods. This leads to the release of peptides from the cell surface proteins. This study presents, to the best of our knowledge, the first use of the shaving method on a $S$. thermophilus strain. The results have been very successful, not only because the shaving allowed us proving that the heterologous proteins were actually expressed but it also allowed detecting other proteins on the cell surface of the mutants and the wild-type strain. Forty-three proteins were thus identified. Searching their subcellular locations either by using the Uniprot data bank or by similarity to subcellular located proteins [35] revealed 17 proteins defined as cell surface (CS), or membrane-located (M) proteins, 22 cytoplasmic proteins and four uncharacterised proteins (Additional file 1: shaving results A). Only two cytoplasmic proteins were identified in all samples: the elongation factor $\mathrm{Tu}$ and the ATP-binding subunit of Clp protease and DnaK/DnaJ chaperones (Additional file 1: shaving results A). To estimate the abundance of each protein in each 
sample compared to all detected proteins, we calculated the protein content in percent using the following formula: ((emPAI of CS $+\mathrm{M}) /$ total emPAI $) \times 100$ [31]. Thus extracellular proteins $(C S+M)$ represented $99.97 \%$, 99.92\%, 98.82\% and $99.92 \%$ of all detected proteins for PrtS ${ }^{-}$mutant, LMD-9, PrtH ${ }^{+}$mutant and $\mathrm{PrtH}^{+}$WANS mutant, respectively.

The identification of few intracellular proteins, at a low level, is intrinsic to shaving [36] and can be explained either by a slight cell lysis during shaving leading to the release of intracellular proteins [37] or to the presence of moonlighting multitask proteins such as enolase [38].

Regarding the CEPs, PrtS, PrtH ${ }^{+}$and $\operatorname{PrtH}^{+}$WANS were identified in shaving supernatants of $S$. thermophilus LMD-9 wild-type strain, PrtH ${ }^{+}$mutant and PrtH $^{+}$WANS mutant, respectively, while no CEP was identified for PrtS $^{-}$mutant strain (Table 1). As no signal peptide was identified, this suggests that the three CEPs were excreted through the Sec system, and consequently located on the cell-wall of $S$. thermophilus. So, if the first amino acids following the signal sequence are crucial for the translocation by the sec system (see "Strategy of the mutant constructions" in the Results part), we showed that the peculiar sequence present in PrtH of L. helveticus is functional in S. thermophilus. The wild-type strain S. thermophilus LMD-9 secretes PrtS CEP covalently anchored to the cell-wall [39]. This protein was highly abundant as shown by the high value of the emPAI (Table 1 and Additional file 1: shaving results A). This was also the case for $\mathrm{PrtH}^{+}$WANS, but not for $\mathrm{PrtH}^{+}$. This suggests that PrtH $^{+}$WANS is probably covalently anchored to the cellwall of S. thermophilus LMD-9, by the action of the sortase SrtA which recognizes the LPXTG motif, as it is the case for PrtS. Thus, the anchored system could be crucial for having highly abundant protein at the cell surface and it appears that the S-layer motif arising from $L$. helveticus strain seemed less adapted than the LPXTG motif to attach proteins to the cell-wall of $S$. thermophilus. Indeed, the emPAI of $\mathrm{PrtH}^{+}$don't rank it among the most abundant proteins detected in its sample, contrary to PrtH $^{+}$WANS (Additional file 1: shaving results A). This difference is also encountered with the number of identified peptides as 40 peptides were identified for CEP of $\mathrm{PrtH}^{+}$mutant against 84 peptides for $\mathrm{PrtH}^{+} \mathrm{WANS}$ mutant (Figure 4A and Additional file 1: shaving results $\mathrm{C}$ and D). The lower number of $\mathrm{PrtH}^{+}$identified peptides could be explained by a lower interaction of $\mathrm{PrtH}^{+}$with the cell-wall leading to its higher release into the extracellular medium. Indeed, the absence of S-layer proteins surrounding the cell of $S$. thermophilus could have impaired the interaction between the $\mathrm{W}$ domain of PrtH and the peptidoglycan [33,34]. Actually, $\mathrm{Hu}$ et al. [40] showed that an excess of fusion green fluorescent protein (GFP) harbouring a S-layer motif incubated one hour with
S. thermophilus and Lc. lactis cells was able to be fixed on their surface but at low level compared to other LAB expressing S-layer proteins on their cell-wall.

Regarding the PrtS maturation, peptide LSVADET TAITNQEEAKPQ, corresponding to the C-terminal extremity of the PP domain, and peptide NIDSNTIITVPK to the N-terminal end of the PR domain were detected, which does not correspond to the theoretical cleavage sites for trypsin (Figure 4B). They could result from a cleavage between the last residue $(\mathrm{Q})$ of the PP domain and the first residue $(\mathrm{N})$ of the $\mathrm{PR}$ domain that occurs during the maturation process of PrtS, as shown by Fernandez-Espla et al. [25] and Chang et al. [41]. The concomitant presence of the complete sequence of the peptide LSVADETTAITN QEEAKPQNIDSNTIITVPK suggested that some PrtS molecules were also in their immature form, as stated by Chang et al. [41]. As both mature and immature forms were present at the cell surface, the maturation step could occur after the CEP anchoring.

\section{CEP activity issues}

The activity of $\operatorname{PrtH}^{+}$and $\operatorname{PrtH}^{+}$WANS was neither detected at the cell surface of $S$. thermophilus nor in the medium. Moreover, cell-wall heterologous CEPs secreted in S. thermophilus mutants were not active on $\beta$ and $\alpha_{s 1}{ }^{-}$ caseins in contrast to the cells of wild-type strains of L. helveticus [30] and S. thermophilus LMD-9 (results not shown). This lack of activity could explain the difference of growth rate observed in milk between mutants and the wild-type strain. One hypothesis to explain the inactivity of the PrtH is the presence of a mutation in the gene sequence. Indeed, in this study, the strain $L$. helveticus CNRZ32 CIRM-BIA 103 was used (Accession: PRJEB1537; Taxonomy ID: 1226332) and the analysis of its $p r t H$ gene sequence revealed an unexpected difference compared to that of $L$. helveticus CNRZ32 prtH sequence previously published [GenBank: AF133727.1; GI: 5758038] although both strains derived from the same initial strain of the CNRZ collection. This difference consisted of a 83 aa residues imperfect duplication which overlaps the end of the $\mathrm{H}$ domain and the beginning of the $\mathrm{W}$ domain. This insertion, which extends twice the helix domain $\mathrm{H}$, may change the conformation of the protein, the way it can be included in the cell wall or the environment around the catalytic domain PR. Previous works showed that the strains of L. helveticus CIRM-BIA 103 and CNRZ32 contain four protease genes, and showed a similar specific activity of the cell envelope proteinases [30], but it is not possible to know whether all CEPs are really active or only some of them.

A second hypothesis is that the heterologous PrtH could be immature. This was observed for $\mathrm{PrtH}^{+} \mathrm{WANS}$ mutant, with the identification of the peptide VYYANDSSADN MANVSTVWNNYK (Additional file 1: shaving results D) 
which overlaps the PP and PR domains of PrtH ${ }^{+}$WANS CEP. In the case of L. helveticus, the maturation process could involve another actor to obtain a functional CEP. L. helveticus CNRZ32 has two maturation proteins in the chromosome belonging to the peptidylprolyl cis/trans isomerase family [23], named PrtM [UniProtKB/TrEMBL: A4UAD9] and PrtM2 [UniProtKB/TrEMBL: A4UAE0]. According to Broadbent et al. [23], PrtM could be required for PrtH maturation whereas PrtM2 should have a role in maturation of the other L. helveticus CEPs. Even if the maturation mechanism on S. thermophilus cell-wall is still not well established, this species does not seem to secrete maturase [5]. Maturation of PrtS could be achieved through an automaturation process or other factors not yet identified. One potential experiment to promote maturation of PrtH on the cell surface could be to introduce the prtM gene from $L$. helveticus CNRZ32 in $\mathrm{PrtH}^{+} \mathrm{WANS}$ mutant chromosome. However, this experiment requires multiple mutant constructions to expect to obtain active heterologous proteinases. Indeed, the expression level required to efficiently act on $\mathrm{PrtH}$ and the location and anchoring of PrtM on the bacterium surface are still ambiguous.

Finally, the lack of activity could be due to the chosen host and/or to the selected heterologous protein. Indeed, we cannot exclude that the microenvironment of the cell-wall (presence or absence of S-layer proteins) may influence the correct folding of the enzyme. This latter problem is also encountered in the other hosts commonly used for heterologous secretion. Furthermore, although PrtS activity on the cell-wall of S. thermophilus was demonstrated $[29,41,42]$, the quantity of secreted proteins by this pathway is still unknown in S. thermophilus LMD-9 and heterologous CEPs as well as PrtS may be displayed at a too low level on the cell surface to detect the activity of heterologous CEPs. Anyway, despite the lack of activity, our tool actually allows secretion and anchoring of proteins of high molecular weight at the cell surface of S. thermophilus.

\section{Conclusion}

This study demonstrated that S. thermophilus LMD-9 strain is able to secrete and probably anchor heterologous proteins on its cell-wall and gives a new tool to enlarge the panel of heterologous secretion hosts. This $S$. thermophilus strain is a powerful tool regarding its ability for natural competence that allows bypassing plasmid construction to produce recombinant proteins. Moreover, its food grade status added to its wide industrial use and its ability to survive in gastrointestinal tract make S. thermophilus LMD-9 a good candidate to release recombinant proteins in a dairy matrix or directly in gastrointestinal tract. At this stage, our tool requires selection genes to be constructed which could constitute a negative point in most applications. However, we can imagine to dispense with the use of a selection gene for further constructions, thanks to the highly transformation rate of S. thermophilus LMD-9 [14,15,17].

\section{Methods}

\section{Bacterial strains and growth conditions}

Strains used in this work were Lactobacillus helveticus CNRZ32 CIRM-BIA 103, Streptococcus thermophilus LMD-9 [43], S. thermophilus LMD-9 TIL1193 [18] and three S. thermophilus LMD-9 mutants: $\mathrm{PrtH}^{+}$, $\mathrm{PrtS}^{-}$ and $\operatorname{PrtH}^{+}$WANS (this study). They were cultivated at $42^{\circ} \mathrm{C}$, in MRS (Difco) for L. helveticus and in M17 supplemented with $2 \%$ of lactose (LM17) [44] for S. thermophilus strains. For natural transformation experiments, LM17 and reconstituted chemically defined medium (CDM) supplemented with $2 \%$ of lactose (LCDM) [45] were used. A $10 \%$ reconstituted skim milk was used for strain conservation and precultures of $S$. thermophilus strains. When necessary, antibiotics were added to the media: erythromycin (Sigma) at $5 \mu \mathrm{g} . \mathrm{mL}^{-1}$ (for cultures of $\mathrm{PrtH}^{+}$and $\mathrm{PrtS}^{-}$mutants) or kanamycin (Sigma) at $1 \mathrm{mg} \cdot \mathrm{mL}^{-1}$ (for culture of $\mathrm{PrtH}^{+}$WANS mutant). The absorbance at $480 \mathrm{~nm}$ of skim milk cultures was measured after 1:10 dilution in a clarification solution of EDTA $0.2 \%$ (pH 12).

\section{DNA extraction and PCR}

General molecular biology techniques, DNA extraction and PCR amplifications were achieved according to Green and Sambrook [46], and/or supplier's recommendations. PCR fragments were obtained using the Taq DNA polymerase or the Phusion high fidelity DNA polymerase (Fermentas, Saint Rémy-lès-Chevreuse, France) in a Mastercycler proS (Eppendorf). All primers used in this work are listed in Table 2 and in Additional file 2: sequencing primers and Additional file 3: qPCR primers. They were designed by using Primer3Plus [47] and purchased from Eurogentec (Seraing, Belgium). To produce overlapping regions between adjacent fragments (see above), a short nucleotide sequence homologous to the beginning of the adjacent fragment was added at the $5^{\prime}$ end of one of the primer used to amplify the desired fragment (in italics in Table 2).

For DNA constructions, each PCR fragment was first amplified with Phusion high fidelity DNA polymerase with the minimum of DNA matrix i.e. enough to have 500 to 1000 matrix copy per PCR reaction. PCR were performed according to polymerase supplier's recommendations. Fragments were then purified using high pure PCR product purification kit (Roche Applied Science, Meylan, France) and eluted in elution buffer as recommended by Fontaine et al. [17]. For both constructions produced by OL PCR, the four purified fragments were pooled in equal amount and PCR-amplified, in a final volume of $20 \mu \mathrm{L}$, 
Table 2 Primers and resulting fragments used in overlap extension PCR for construction of PrtH ${ }^{+}$and PrtH $^{+}$WANS mutants $^{2}$

\begin{tabular}{|c|c|c|c|c|c|c|c|c|}
\hline Fragment & Primer & Sequence $\left(5^{\prime}-3^{\prime}\right)$ & $\begin{array}{l}\text { Length } \\
\text { (bp) }\end{array}$ & $\begin{array}{l}\text { DNA matrix } \\
\text { (strain) }\end{array}$ & $\begin{array}{l}\text { Product size } \\
\quad \text { (kbp) }\end{array}$ & $\begin{array}{l}\text { Hyb temp } \\
\left({ }^{\circ} \mathrm{C}\right)\end{array}$ & $\begin{array}{l}\text { Overlap product } \\
\text { size (kbp) }\end{array}$ & $\begin{array}{l}\text { Overlap hyb } \\
\text { temp }\left({ }^{\circ} \mathrm{C}\right)\end{array}$ \\
\hline \multicolumn{9}{|l|}{$\mathrm{PrtH}^{+}$} \\
\hline \multirow[t]{2}{*}{$\mathrm{F} 1$} & Style $1-1^{*}$ & ACAAATTCATGCCGTTCATAAG & 22 & \multirow{2}{*}{ gDNA (LMD-9) } & \multirow{2}{*}{0.986} & \multirow{2}{*}{59.5} & & \\
\hline & $\operatorname{PrtSss} U p(H) \_R$ & GCCTTAACTTGTTGTTCTGCAGCTACCGATGGTGC & 35 & & & & & \\
\hline \multirow[t]{2}{*}{ F2 } & PrtHpp_F & GAACAACAAGTTAAGGCTAGTGTTGACAGCCAAACAAAAAC & 41 & \multirow[b]{2}{*}{$\begin{array}{l}\text { gDNA (CNRZ32 } \\
\text { CIRM-BIA 103) }\end{array}$} & \multirow[b]{2}{*}{5.752} & \multirow[b]{2}{*}{62} & & \\
\hline & PrtHterm_R & $\begin{array}{l}\text { AAAAGAGTAATGATCCTTCTCATTACTCTITCATTATATGTAAATG } \\
\text { ATTATITAC }\end{array}$ & 56 & & & & & \\
\hline \multirow[t]{2}{*}{ F3 } & EmpG9(H)_F & GAGAAGGATCATTACTCTTTTCAAACTTAAGAGTGTGTTGATAGTGC & 47 & \multirow[b]{2}{*}{ pG+host 9} & \multirow[b]{2}{*}{0.969} & \multirow[b]{2}{*}{59.5} & & \\
\hline & EmpG9_R & GGACCTCTTTAGCTCCTTGG & 20 & & & & & \\
\hline \multirow[t]{2}{*}{ F4 } & $\operatorname{PrtSDn}(E m) \_F$ & CCAAGGAGCTAAAGAGGTCCATAATAAAACCGCTTAATCATTGTG & 45 & \multirow{2}{*}{ gDNA (LMD-9) } & \multirow{2}{*}{0.973} & \multirow{2}{*}{49} & & \\
\hline & PrtSDn_R & CGTCTATCAATCTTGTATTITCTTG & 25 & & & & & \\
\hline \multicolumn{9}{|l|}{$\mathrm{PrtH}^{+}$WANS } \\
\hline \multirow[t]{2}{*}{ F5 } & UpH_F & CGGTATCAAGTGGGGTACTCG & 21 & \multirow{2}{*}{ gDNA (PrtH+) } & \multirow{2}{*}{1.395} & \multirow{2}{*}{69} & & \\
\hline & UpH(WANS)_R & CTTGCTTGGCTTGCAGAAACAGGAGCTGCAACTTGGTTATC & 41 & & & & & \\
\hline \multirow[t]{2}{*}{ F6 } & WANS_F & TCTGCAAGCCAAGCAAG & 17 & \multirow{2}{*}{ gDNA (LMD-9) } & \multirow{2}{*}{0.473} & \multirow{2}{*}{58} & & \\
\hline & WANS(aphA3)_R & CTCAAATGGTTCGCTGGTIAGCAAACTTGTGATAAAGC & 38 & & & & 4106 & 5 \\
\hline \multirow[t]{2}{*}{ F7 } & aphA3_F** & CCAGCGAACCATTTGAG & 17 & \multirow{2}{*}{ gDNA (TIL1193) } & \multirow{2}{*}{1.4} & \multirow{2}{*}{54} & 4.180 & 55 \\
\hline & aphA3_R** & GTTGCGGATGTACTTCAG & 18 & & & & & \\
\hline \multirow[t]{2}{*}{ F4 } & $\operatorname{PrtSDn}(a p h A 3) \_F$ & CTGAAGTACATCCGCAACATAATAAAACCGCTTAATCATTGTG & 43 & \multirow{2}{*}{ gDNA (LMD-9) } & \multirow{2}{*}{0.971} & \multirow{2}{*}{61.7} & & \\
\hline & PrtSDn_R & CGTCTATCAATCTTGTATTTCTTG & 25 & & & & & \\
\hline
\end{tabular}

Primers Style 1-1, PrtSDn_R, and UpH_F correspond to those used for overlapping PCR reaction and italicised nucleotides correspond to homologous tails.

The name, sequence, length, DNA matrix, product size (including the added tails), hybridization temperature (hyb temp), overlap product size and overlap hybridisation temperature (hyb temp) are indicated. bp (base pairs); kbp (kilobase pairs) and gDNA (genomic DNA) *[42], **[18]. 
with the forward primer of the $5^{\prime}$ end fragment and the reverse primer of the $3^{\prime}$ end fragment (Table 2). For sequencing, PCR fragments were amplified with the Taq polymerase and sequencing primers (Additional file 2: sequencing primers) and shipped to the company Beckman Coulter Genomics (Essex, U.K.).

\section{Genetic material and mutant constructions}

Four DNA matrices were used for mutant constructions: the prtH gene [locus_tag: LHCIRMBIA103_00753; NCBI Accession Number: PRJEB1537; Taxonomy ID: 1226332] of L. helveticus CNRZ32 CIRM-BIA 103 (Figure 1A), the prtS gene [locus tag: STER_0846; NCBI Reference Sequence: YP_820283.1; GI: 116627664] from S. thermophilus LMD-9 (Figure 1B), the erythromycin resistance gene (Figure 1C) from pG+host9 plasmid DNA [48] and the kanamycin resistance gene (Figure 1D) from $S$. thermophilus LMD-9 TIL1193 genomic DNA (gDNA) [18].

Two constructions were obtained using OL PCR. Primers used for OL PCR are described in Table 2. The prt $H^{+} 8622$ bp construction was produced by assembling 4 fragments in this order: F1, F2, F3 and F4 (Figure 2). For F1 and F4 respectively, a 969 bp sequence composed of the promoter, RBS, and S domain of prtS and the $953 \mathrm{bp}$ downstream region of prtS fragment starting 33 nt after prtS stop codon were amplified from $S$. thermophilus LMD-9 gDNA (Figure 1B). For F2, a 5752 bp region of the $p r t H$ open reading frame (ORF) sequence, from PP to 46 nt after stop codon was amplified from $L$. helveticus CNRZ32 CIRM-BIA 103 gDNA (Figure 1A). For F3, a 948 bp sequence (Figure 1C) containing an erythromycin resistance gene was amplified from pG+host9 plasmid DNA [48].

The prt $H^{+} W A N S 4186$ bp construction results from the assembly of 4 fragments F5, F6, F7 and F4 (Figure 2B). For F5, a 1378 bp region composed of the last 817 nt of $B$ domain, the $\mathrm{H}$ domain and the first $96 \mathrm{nt}$ of $\mathrm{W}$ domain of prtH excluding the S-layer sequence was amplified from L. helveticus CNRZ32 CIRM-BIA 103 gDNA (Figure 1A). For F6, a 456 bp sequence with $\mathrm{W}$ and AN domains of prtS plus $30 \mathrm{nt}$ after prtS stop codon was amplified from S. thermophilus LMD-9 gDNA (Figure 1B). For F7, a 1400 bp sequence of kanamycin resistance gene (Figure 1D) was amplified from S. thermophilus LMD-9 TIL1193 gDNA [18]. The F4 region was the same as the one used for $\mathrm{PrtH}^{+}$construction.

\section{Natural transformation}

Linear DNA fragments obtained by OL PCR were introduced in $S$. thermophilus LMD-9 by natural transformation as described by Gardan et al. [18]. Briefly, S. thermophilus LMD-9 was grown at $42^{\circ} \mathrm{C}$ in chemically defined medium (CDM) during 5-6 hours, until $\mathrm{OD}_{600} \mathrm{~nm}=1.8-2$ (exponential growth phase). Culture was then diluted in CDM in order to obtain $\mathrm{OD}_{600 \mathrm{~nm}}=0.05$ and incubated at $42^{\circ} \mathrm{C}$ about 1 hour, until $\mathrm{OD}_{600 \mathrm{~nm}}$ reached 0.2 . Then, $100 \mu \mathrm{L}$ of culture was mixed with $3 \mu \mathrm{L}$ of OL PCR product and incubated $30 \mathrm{~min}$ at $42^{\circ} \mathrm{C}$. After the adding of $900 \mu \mathrm{L}$ of LM17, the mixture was re-incubated $40 \mathrm{~min}$ at $42^{\circ} \mathrm{C}$. Cells were then concentrated 10 times by centrifugation $(5 \mathrm{~min}$, $3900 \mathrm{~g}$ ) and resuspension with their own supernatant, and spread on LM17 agar plates supplemented with the appropriate antibiotic.

The $p r t H^{+}$OL PCR fragment was introduced into S. thermophilus LMD-9 to obtain a PrtH ${ }^{+}$mutant. Likewise, the prt $H^{+} W A N S$ OL PCR fragment was introduced in the $\mathrm{PrtH}^{+}$mutant to obtain the PrtH ${ }^{+}$WANS mutant. Integration of OL PCR fragments at the targeted locus is achieved through the presence of 2 fragments of approximately $1000 \mathrm{bp}$ homologous to the targeted locus and surrounding the foreign DNA. These homologous regions were included into the F1 or F5, and F4 fragments (Figures 1 and 2).

\section{RNA extraction, reverse transcription and quantitative real-time PCR}

S. thermophilus LMD-9, PrtS ${ }^{-}, \operatorname{PrtH}^{+}$and $\operatorname{PrtH}^{+}$WANS were grown in skim milk up-to $\mathrm{OD}_{480 \mathrm{~nm}}=1-2$ (exponential growth phase), before milk coagulation. Milk caseins were removed according Chopard et al. [49]: at $6 \mathrm{~mL}$ of skim milk culture were added $795 \mu \mathrm{L}$ of saline solution ( $\mathrm{NaCl}$ 0.85\% (wt/v); sodium glycerophosphate 0.5\% (wt/v); tween $800.1 \%(\mathrm{v} / \mathrm{v}) ; \mathrm{pH} 7)$ and $195 \mu \mathrm{L}$ of trisodium citrate solution $1 \mathrm{M}$. The cell pellets were harvested by centrifugation (15 min, $3900 \mathrm{~g}$ at $4^{\circ} \mathrm{C}$ ) and a second washing with the same solutions was done. The following step was performed using the RNA extract Kit Aurum (Bio-Rad, Marnes La Coquette, France) and cell lysis step was modified as follows: to improve cell lysis, an ultrasonic bath (Bioruptor, Diagenode, Liège, Belgium) (15 s 4 times at maximal power) was performed twice. An additional mechanic milling with $250 \mathrm{mg}$ of $\varnothing 0.1-0.25 \mathrm{~mm}$ glass beads (Fisher Scientific, Illkirch, France) was also performed in $2 \mathrm{~mL}$ microtubes by vortexing first $60 \mathrm{~s}$ then twice $30 \mathrm{~s}$, with at least 2 min stay on ice between each milling. The supernatant was collected after centrifugation at $12,000 \mathrm{~g}$ for $1.5 \mathrm{~min}$ at room temperature.

After nucleic acids extraction, two DNAse steps were performed: a first step with DNAse I (Bio-Rad) followed by a phenol-chloroform extraction [46] and a second step with RNase-free DNase I (Ambion, Courtaboeuf, France). The last step was repeated until PCR control with sigma70 primers was negative after 30 PCR cycles [42]. Total RNA concentrations were determined by measuring the absorbance at $260 \mathrm{~nm}$ using a spectrophotometer Nanodrop-1000 (Thermo Scientific, Illkirch, France). Complementary DNAs (cDNA) were synthesized from $1 \mu \mathrm{g}$ of RNA by using Moloney 
murine leukemia virus reverse transcriptase (Invitrogen, Saint Aubin, France) according to the manufacturer's instructions.

Quantitative PCR (qPCR) reactions were performed on CFX96 Touch $^{\text {TM }}$ Real-Time PCR Detection System (Biorad) following manufacturer's instructions. qPCR primers were designed with Primer3Plus software [47] to amplify approximately 130 bp fragments of: sigma70/sigma32 (reference gene), prtS (positive control) and prtH (Additional file 3: qPCR primers). Serial dilutions of each cDNA sample (LMD-9, PrtH ${ }^{+}$and $\operatorname{PrtH}^{+}$WANS) were carried out to check efficiency of each primer pair and obtain standard curves $(\mathrm{Ct}=\mathrm{f}(\log$ initial $\mathrm{cDNA}$ concentration $))$. Relative quantities were obtained after comparing to the standard curves and normalized using the following formula: $\mathrm{R}=$ (relative quantity of gene of interest)/(relative quantity of reference gene). Ratios obtained for $p r t H$ gene in $\mathrm{PrtH}^{+}$and $\mathrm{PrtH}^{+}$WANS mutants were then compared to that of prtS gene in LMD-9. Quantification was carried out twice independently and the mean and SEM (Standard Error of Mean) were determined.

\section{Surface tryptic digestion of live cells (shaving)}

S. thermophilus LMD-9 wild-type and the three mutants were grown at $42^{\circ} \mathrm{C}$ in $50 \mathrm{~mL}$ of $10 \%$ reconstituted skim milk to $\mathrm{OD}_{480 \mathrm{~nm}}=2$ (exponential growth phase). Cells were washed first in tri-sodium citrate solution $0.25 \mathrm{M}$ (Carlo Erba, Val de Reuil, France) and centrifuged at $500 \mathrm{~g}$, $10 \mathrm{~min}$ at $4^{\circ} \mathrm{C}$. The supernatants containing bacterial cells were then centrifuged at $8,000 \mathrm{~g}, 10 \mathrm{~min}$ at $4^{\circ} \mathrm{C}$ and washed at least three times with $100 \mathrm{mM}$ Tris- $\mathrm{HCl}, \mathrm{pH} 7.5$ containing $150 \mathrm{mM} \mathrm{NaCl}$ to remove the residual caseins. Washed cells were concentrated to $\mathrm{OD}_{650 \mathrm{~nm}}=30$ and suspended in PBS containing $5 \mathrm{mM}$ DL-Dithiothreitol (Sigma-Aldrich, St Quentin Fallavier, France) solution, adjusted to $\mathrm{pH}$ 8.5. Five $\mu \mathrm{g}$ of sequenced grade trypsin (Promega, Charbonnières, France) were added to $500 \mu \mathrm{L}$ of the concentrated cell solution. In parallel, negative controls were carried out by adding the trypsin buffer without the enzyme. Cells were incubated 1 hour at $37^{\circ} \mathrm{C}$ with shaking (180 rpm). Supernatants were harvested by centrifugation at 10,000 g, $10 \mathrm{~min}$ at room temperature and filtrated through a $0.45 \mu \mathrm{m}$ filter (Millex PVDF, $13 \mathrm{~mm}$, Millipore, Molsheim, France). Supernatants were incubated overnight at $37^{\circ} \mathrm{C}$ with shaking $(100 \mathrm{rpm})$ in presence of $1 \mu \mathrm{g}$ of trypsin. The reaction was stopped by adding $15 \mu \mathrm{L}$ TriFluoroacetic Acid (TFA) 10\% (v/v) (Sigma Aldrich) and samples were stored at $-20^{\circ} \mathrm{C}$ before mass spectrometry analysis.

\section{Tandem mass spectrometry}

Mass spectrometry (MS) experiments were performed using a nanoRSLC Dionex U3000 system fitted to a Q Exactive mass spectrometer (Thermo Scientific, San Jose,
USA) equipped with a nanoelectrospray ion source. A preliminary sample concentration step was performed on a nanotrap PepMap $100(\mathrm{C} 18,3 \mu \mathrm{m}, 75 \mu \mathrm{m}$ Inner Diameter (ID) $\times 20 \mathrm{~mm}$ Length (L)) (Dionex, Amsterdam, Netherlands). Separation was performed on a reverse-phase column PepMap RSLC C18 $3 \mu \mathrm{m}, 100 \AA$ (75 $\mu \mathrm{m}$ ID, $150 \mathrm{~mm} \mathrm{~L}$ ) (Dionex, Amsterdam, Netherlands) at $35^{\circ} \mathrm{C}$, using solvent A ( $2 \%(\mathrm{v} / \mathrm{v})$ acetonitrile, $0.08 \%(\mathrm{v} / \mathrm{v})$ formic acid and $0.01 \%(\mathrm{v} / \mathrm{v})$ TFA in deionized water) and solvent $\mathrm{B}(95 \%(\mathrm{v} / \mathrm{v})$ acetonitrile, $0.08 \%(\mathrm{v} / \mathrm{v})$ formic acid and $0.01 \%(\mathrm{v} / \mathrm{v})$ TFA in deionized water). $5-60 \%$ of solvent $\mathrm{B}$ in $46 \mathrm{~min}$ and $60-80 \%$ in $1 \mathrm{~min}$ was applied as separation gradient at a flow rate of $0.3 \mu \mathrm{L} / \mathrm{min}$. Eluted peptides were directly electrosprayed into the mass spectrometer operated in positive mode and a voltage of $2 \mathrm{kV}$ with the help of a Proxeon Nanospray Flex ion source (Thermo Scientific, San Jose, USA). Spectra were recorded in full MS mode and selected in a mass range $300-2000 \mathrm{~m} / \mathrm{z}$ for MS spectra with a resolution of 70,000 at $\mathrm{m} / \mathrm{z} 200$. For each scan, the ten more intense ions were selected for fragmentation. MS/MS spectra were recorded with a resolution of 17,500 at $\mathrm{m} / \mathrm{z} 200$ and the parent ion was subsequently excluded of the analysis during $15 \mathrm{~s}$. The instrument was externally calibrated according to the supplier's procedure.

To identify peptides, all data (MS and MS/MS) were submitted to $\mathrm{X}$ ! Tandem using the $\mathrm{X}$ ! Tandem pipeline developed by PAPPSO (Plateforme d'Analyse Protéomique de Paris Sud-Ouest (PAPPSO), INRA, Jouy-en-Josas, France, http://pappso.inra.fr).

The search was performed against a database composed of the taxonomy Bacilli from www.uniprot.org (Taxon identifier: 91061) to which was added the deduced sequences of the two proteins of $\mathrm{PrtH}^{+}$and $\mathrm{PrtH}^{+}$WANS. Database search parameters were specified as follows: trypsin cleavage was used and the peptide mass tolerance was set to $10 \mathrm{ppm}$ for MS and 0.02 Da for MS/MS. Oxidation of methionine was selected as a variable modification. Semitryptic peptides were allowed during the "refinement" process of X!tandem. For each peptide identified, a minimum score corresponding to an e-value below 0.05 was considered as a prerequisite for peptide validation.

The identified proteins were conserved when at least three specific peptides were identified.

\section{Additional files}

Additional file 1: Proteins identified after cell surface shaving of S. thermophilus strains PrtS ${ }^{-}, \mathrm{LMD}_{-} 9, \mathrm{PrtH}^{+}$and $\mathrm{PrtH}^{+}$WANS.

Additional file 2: Sequencing primers.

Additional file 3: Primers used for qPCR experiments.

Competing interests

The authors declare that they have no competing interests. 


\section{Authors' contributions}

$\mathrm{XL}$ carried out the experiments and contributed to the redaction of the manuscript. VG supervised shaving experiments and results analysis and contributed to the redaction. VBB provided technical assistance for mass spectrometry. JJ provided experience and knowledge for mass spectrometry. $\mathrm{SL}$ initiated this work and corrected the manuscript. AD initiated and supervised this work. MG supervised the project and contributed to the redaction of the manuscript. All authors read and approved the final manuscript.

\section{Acknowledgements}

We are grateful to Dr. Rozenn GARDAN for her advices in CDM and natural transformation methods, Dr. Wessam GALIA for his help in qPCR data analysis and Dr. Gwenaël JAN for his help in shaving method. We also thank Dr. Zeeshan HAFEEZ for his language corrections.

L. helveticus CNRZ32 CIRM-BIA 103 was kindly provided by the Centre International de Ressources Microbiennes-Bactéries d'Intérêt Alimentaire, INRA, Rennes, France.

Xavier LECOMTE is the recipient of a Ph.D. fellowship from the "Ministère de l'Enseignement Supérieur et de la Recherche". This work was financially supported by the Région Lorraine and the Région Bretagne.

\section{Author details}

${ }^{1}$ Unité de Recherche Animal et Fonctionnalités des Produits Animaux, Equipe Protéolyse et Biofonctionnalité des Protéines et des Peptides, Université de Lorraine, Vandœuvre-lès-Nancy F-54506, France. ${ }^{2}$ INRA, UR AFPA Unité Sous Contrat 340, Vandœuvre-lès-Nancy F-54506, France. ${ }^{3}$ UMR 1253, INRA, Science et Technologie du Lait et de I'CFuf, Rennes, France. ${ }^{4}$ UMR 1253, Agrocampus Ouest, Science et Technologie du Lait et de I'CFuf, Rennes, France.

Received: 10 January 2014 Accepted: 27 May 2014

Published: 5 June 2014

\section{References}

1. Bernaudat F, Frelet-Barrand A, Pochon N, Dementin S, Hivin P, Boutigny S, Rioux JB, Salvi D, Seigneurin-Berny D, Richaud P, Joyard J, Pignol D, Sabaty M, Desnos T, Pebay-Peyroula E, Darrouzet E, Vernet T, Rolland N: Heterologous expression of membrane proteins: choosing the appropriate host. PLoS One 2011, 6(12):e29191.

2. Le Loir $Y$, Azevedo V, Oliveira SC, Freitas DA, Miyoshi A, Bermudez-Humaran LG, Nouaille S, Ribeiro LA, Leclercq S, Gabriel JE, Guimaraes VD, Oliveira MN, Charlier C, Gautier M, Langella P: Protein secretion in Lactococcus lactis: an efficient way to increase the overall heterologous protein production. Microb Cell Fact 2005, 4:2.

3. Westers L, Westers H, Quax WJ: Bacillus subtilis as cell factory for pharmaceutical proteins: a biotechnological approach to optimize the host organism. Biochim Biophys Acta-Mol Cell Res 2004, 1694:299-310.

4. Morello E, Bermudez-Humaran LG, Llull D, Sole V, Miraglio N, Langella P, Poquet I: Lactococcus lactis, an efficient cell factory for recombinant protein production and secretion. J Mol Microbiol Biotechnol 2008, 14:48-58.

5. Zhou MM, Theunissen D, Wels M, Siezen RJ: LAB-Secretome: a genome-scale comparative analysis of the predicted extracellular and surface-associated proteins of Lactic Acid Bacteria. BMC Genomics 2010, 11:651.

6. Wydau S, Dervyn R, Anba J, Ehrlich SD, Maguin E: Conservation of key elements of natural competence in Lactococcus lactis ssp. FEMS Microbiol Lett 2006, 257:32-42

7. Johnsborg O, Eldholm V, Havarstein LS: Natural genetic transformation: prevalence, mechanisms and function. Res Microbiol 2007, 158:767-778.

8. Elli M, Callegari ML, Ferrari S, Bessi E, Cattivelli D, Soldi S, Morelli L, Feuillerat NG, Antoine JM: Survival of yogurt bacteria in the human gut. Appl Environ Microbiol 2006, 72:5113-5117.

9. Mater DDG, Bretigny L, Firmesse O, Flores MJ, Mogenet A, Bresson JL, Corthier G: Streptococcus thermophilus and Lactobacillus delbrueckii subsp. bulgaricus survive gastrointestinal transit of healthy volunteers consuming yogurt. FEMS Microbiol Lett 2005, 250:185-187.

10. Guarner F, Perdigon G, Corthier G, Salminen S, Koletzko B, Morelli L: Should yoghurt cultures be considered probiotic? Br J Nutr 2005, 93:783-786.

11. Solaiman DKY, Somkuti GA: Construction of a green-fluorescent proteinbased, insertion-inactivation shuttle vector for lactic acid bacteria and Escherichia coli. Biotechnol Lett 1997, 19:1175-1179.
12. Somkuti GA, Solaiman DKY, Johnson TL, Steinberg DH: Transfer and expression of A streptomyces cholesterol oxidase gene in Streptococcus thermophilus. Biotechnol Appl Biochem 1991, 13:238-245.

13. Renye JA, Somkuti GA: Vector-mediated chromosomal integration of the glutamate decarboxylase gene in Streptococcus thermophilus. Biotechnol Lett 2012, 34:549-555.

14. Blomqvist T, Steinmoen $H$, Havarstein LS: Natural genetic transformation: a novel tool for efficient genetic engineering of the dairy bacterium Streptococcus thermophilus. Appl Environ Microbiol 2006, 72:6751-6756.

15. Fontaine L, Dandoy D, Boutry C, Delplace B, De Frahan MH, Fremaux C, Horvath $P$, Boyaval $P$, Hols P: Development of a versatile procedure based on natural transformation for marker-free targeted genetic modification in Streptococcus thermophilus. Appl Environ Microbiol 2010, 76:7870-7877.

16. Fontaine L, Goffin P, Dubout H, Delplace B, Baulard A, Lecat-Guillet N, Chambellon E, Gardan R, Hols P: Mechanism of competence activation by the ComRS signalling system in streptococci. Mol Microbiol 2013, 87:1113-1132.

17. Fontaine L, Boutry C, De Frahan MH, Delplace B, Fremaux C, Horvath $P$, Boyaval $\mathrm{P}$, Hols P: A novel pheromone quorum-sensing system controls the development of natural competence in Streptococcus thermophilus and Streptococcus salivarius. J Bacteriol 2010, 192:1444-1454.

18. Gardan R, Besset C, Guillot A, Gitton C, Monnet V: The oligopeptide transport system is essential for the development of natural competence in Streptococcus thermophilus Strain LMD-9. J Bacteriol 2009, 191:4647-4655.

19. Goh YJ, Goin C, O'Flaherty S, Altermann E, Hutkins R: Specialized adaptation of a lactic acid bacterium to the milk environment: the comparative genomics of Streptococcus thermophilus LMD-9. Microb Cell Fact 2011, 10(Suppl 1):S22.

20. Qin JJ, Li RQ, Raes J, Arumugam M, Burgdorf KS, Manichanh C, Nielsen T, Pons N, Levenez F, Yamada T, Mende DR, Li JH, Xu JM, Li SC, Li DF, Cao JJ, Wang B, Liang HQ, Zheng HS, Xie YL, Tap J, Lepage P, Bertalan M, Batto JM, Hansen T, Le Paslier D, Linneberg A, Nielsen HB, Pelletier E, Renault P, et al: A human gut microbial gene catalogue established by metagenomic sequencing. Nature 2010, 464:U59-U70.

21. Dandoy D, Fremaux C, De Frahan MH, Horvath P, Boyaval P, Hols P, Fontaine $L$ : The fast milk acidifying phenotype of Streptococcus thermophilus can be acquired by natural transformation of the genomic island encoding the cell-envelope proteinase PrtS. Microb Cell Fact 2011, 10(Suppl 1):S21.

22. Sadat-Mekmene L, Genay M, Atlan D, Lortal S, Gagnaire V: Original features of cell-envelope proteinases of Lactobacillus helveticus. A review. Int J Food Microbiol 2011, 146:1-13.

23. Broadbent JR, Cai H, Larsen RL, Hughes JE, Welker DL, De Carvalho VG, Tompkins TA, Ardo Y, Vogensen F, De Lorentiis A, Gatti M, Neviani E, Steele $J$ : Genetic diversity in proteolytic enzymes and amino acid metabolism among Lactobacillus helveticus strains. J Dairy Sci 2011, 94:4313-4328.

24. Genay M, Sadat L, Gagnaire V, Lortal S: prtH2, not prtH, is the ubiquitous cell-wall proteinase gene in Lactobacillus helveticus. Appl Environ Microbiol 2009, 75:3238-3249

25. Fernandez-Espla MD, Garault P, Monnet V, Rul F: Streptococcus thermophilus cell wall-anchored proteinase: release, purification and biochemical and genetic characterization. Appl Environ Microbiol 2000 66:4772-4778

26. Siezen RJ: Multi-domain, cell-envelope proteinases of lactic acid bacteria. Antonie Van Leeuwenhoek 1999, 76:139-155.

27. Bagos PG, Nikolaou EP, Liakopoulos TD, Tsirigos KD: Combined prediction of Tat and Sec signal peptides with hidden Markov models. Bioinformatics 2010, 26:2811-2817.

28. Pederson JA, Mileski GJ, Weimer BC, Steele JL: Genetic characterization of a cell envelope-associated proteinase from Lactobacillus helveticus CNRZ32. J Bacteriol 1999, 181:4592-4597.

29. Shahbal S, Hemme D, Renault P: Characterization of a cell envelopeassociated proteinase activity from Streptococcus thermophilus $\mathrm{H}$-strains. Appl Environ Microbiol 1993, 59:177-182.

30. Sadat-Mekmene L, Jardin J, Corre C, Mollé D, Richoux R, Delage MM, Lortal $\mathrm{S}$, Gagnaire V: Simultaneous presence of $\mathrm{PrtH}$ and $\mathrm{PrtH} 2$ proteinases in Lactobacillus helveticus Strains improves breakdown of the pure alphas1casein. Appl Environ Microbiol 2011, 77:179-186.

31. Ishihama Y, Oda Y, Tabata T, Sato T, Nagasu T, Rappsilber J, Mann M: Exponentially modified protein abundance index (emPAl) for estimation 
of absolute protein amount in proteomics by the number of sequenced peptides per protein. Mol Cell Proteomics 2005, 4:1265-1272.

32. Rappsilber J, Ryder U, Lamond Al, Mann M: Large-scale proteomic analysis of the human splicesome. Genome Res 2002, 12:1231-1245.

33. Delcour J, Ferain T, Deghorain M, Palumbo E, Hols P: The biosynthesis and functionality of the cell-wall of lactic acid bacteria. Antonie Van Leeuwenhoek 1999, 76:159-184.

34. Schleifer $\mathrm{KH}$, Kandler O: Peptidoglycan types of bacterial cell walls and their taxonomic implications. Bacteriol Rev 1972, 36:407-477.

35. Camacho C, Coulouris G, Avagyan V, Ma N, Papadopoulos J, Bealer K, Madden TL: BLAST plus: architecture and applications. BMC Bioinforma 2009, 10:421.

36. Solis N, Larsen MR, Cordwell SJ: Improved accuracy of cell surface shaving proteomics in Staphylococcus aureus using a false-positive control. Proteomics 2010, 10:2037-2049.

37. Olaya-Abril A, Gomez-Gascon L, Jimenez-Munguia I, Obando I, RodriguezOrtega MJ: Another turn of the screw in shaving Gram-positive bacteria: Optimization of proteomics surface protein identification in Streptococcus pneumoniae. J Proteomics 2012, 75:3733-3746.

38. Henderson B, Martin A: Bacterial virulence in the moonlight: Multitasking bacterial moonlighting proteins are virulence determinants in infectious disease. Infect Immun 2011, 79:3476-3491.

39. Marraffini $L A$, Dedent AC, Schneewind O: Sortases and the art of anchoring proteins to the envelopes of gram-positive bacteria. Microbiol Mol Biol Rev 2006, 70:192-221.

40. Hu SM, Kong J, Sun ZL, Han LL, Kong WT, Yang P: Heterologous protein display on the cell surface of lactic acid bacteria mediated by the s-layer protein. Microb Cell Fact 2011, 10:86.

41. Chang OK, Perrin C, Galia W, Saulnier F, Miclo L, Roux E, Driou A, Humbert G, Dary A: Release of the cell-envelope protease PrtS in the growth medium of Streptococcus thermophilus 4 F44. Int Dairy J 2012, 23:91-98.

42. Galia W, Perrin C, Genay M, Dary A: Variability and molecular typing of Streptococcus thermophilus strains displaying different proteolytic and acidifying properties. Int Dairy J 2009, 19:89-95.

43. Makarova K, Slesarev A, Wolf Y, Sorokin A, Mirkin B, Koonin E, Pavlov A, Pavlova N, Karamychev V, Polouchine N, Shakhova V, Grigoriev I, Lou Y, Rohksar D, Lucas S, Huang K, Goodstein DM, Hawkins T, Plengvidhya V, Welker D, Hughes J, Goh Y, Benson A, Baldwin K, Lee JH, Diaz-Muniz I, Dosti B, Smeianov V, Wechter W, Barabote R, et al: Comparative genomics of the lactic acid bacteria. Proc Natl Acad Sci U S A 2006, 103:15611-15616.

44. Terzaghi BE, Sandine WE: Improved medium for lactic Streptococci and their bacteriophages. Appl Microbiol 1975, 29:807-813.

45. Letort C, Juillard V: Development of a minimal chemically-defined medium for the exponential growth of Streptococcus thermophilus. J Appl Microbiol 2001, 91:1023-1029.

46. Green MR, Sambrook J: Molecular Cloning: A Laboratory Manual. N. Y.: Cold Spring Harbor Laboratory Press; 2012.

47. Untergasser A, Nijveen H, Rao X, Bisseling T, Geurts R, Leunissen JAM: Primer3Plus, an enhanced web interface to Primer3. Nucleic Acids Res 2007, 35:W71-W74.

48. Maguin E, Prevost $H$, Ehrlich SD, Gruss A: Efficient insertional mutagenesis in lactococci and other gram-positive bacteria. J Bacteriol 1996, 178:931-935.

49. Chopard MA, Schmitt M, Perrerad E, Chamba JF: Qualitative aspect of proteolytic activity of thermophilic lactobacilli using in Swiss cheeses. Lait 2001, 81:183-194.

\section{doi:10.1186/1475-2859-13-82}

Cite this article as: Lecomte et al:: The naturally competent strain Streptococcus thermophilus LMD-9 as a new tool to anchor heterologous proteins on the cell surface. Microbial Cell Factories 2014 13:82.

\section{Submit your next manuscript to BioMed Central and take full advantage of:}

- Convenient online submission

- Thorough peer review

- No space constraints or color figure charges

- Immediate publication on acceptance

- Inclusion in PubMed, CAS, Scopus and Google Scholar

- Research which is freely available for redistribution

Submit your manuscript at www.biomedcentral.com/submit 